\title{
A.P. Ermolaev and the First Description of Archaeological Collection of the Krasnoyarsk Museum
}

\author{
Anna A. Malitskaya, \\ Nikolai P. Makarov and Alexanrer S. Vdovin* \\ Krasnoyarsk State Pedagogical University named after V.P. Astafev \\ 89 Ada Lebedeva Str., Krasnoyarsk, 660049, Russia
}

Received 23.10.2014, received in revised form 15.01.2015, accepted 12.02.2015

The article represents biography of the Krasnoyarsk city museum conservator assistant A.P. Ermolaev. A brief review of his scientific activity as an archaeologist is given. On the basis of little known archival data, information on details of finding, information collection and publication of the unique Ishimka treasure of the developed Iron Age - Early Middle Ages are published.

Keywords: Museology, the Krasnoyarsk Regional Museum, A.P. Ermolaev, archaeology, Iron Age, Middle Ages, the Ishimka treasure.

Research area: history.

The Krasnoyarsk Museum was founded in 1889, and from the beginning of its foundation, its archaeological collection started to form. The first collections were donated by amateur archaeologists. By the order of the museum, they conducted research, were engaged in archeology, local history and ethnography in their spare time. For over 20 years of the museum existence, excavations were conducted not only in the suburbs of Krasnoyarsk, but in many remote areas of the krai. Among undeservedly forgotten researchers of archaeology and ethnography of the Yenisei region there is also the name of A.P. Ermolaev (1886-1919) [Batashev et al., 2010].

Alexander Petrovich Ermolaev was born on $29^{\text {th }}$ August 1886. Alexander Petrovich's farther (who mastered literacy only at the age of 35) taught him to read from the age of three, often brought pencils and brand new A-B-C books from somewhere. Young Alexander studied easily and with interest. When he was 5 years old, a parochial school was opened in his village and in 1892 it moved to the former house of his family, and his parents settled in it as watchmen. In the same year, Alexander Petrovich went to this school right to the second stage. Life at the school gave him the opportunity to get acquainted with a small school library.

After leaving the parochial school, he entered the Tulunuvskaya forest school. At the entrance exams he got the highest results in all the subjects and therefore was enrolled to the school without any fee on full board basis. Alexander Petrovich graduated from the forest school in 1904 with a

(C) Siberian Federal University. All rights reserved

* Corresponding author E-mail address: anna_malickaya@mail.ru 
certificate of merit and monetary reward. In the end, Ermolaev stayed at the school, gathered collections of birds, insects and herbariums for the forest school. Then, with the assistance of $\mathrm{N}$. Petrov, the head of the same school, he was granted a temporary vacancy in the office of Tulunovsky forestry as a foreman on timber harvesting at the Siberian forest road, where he served from 15 September to 21 November 1904.

After two months of service in Tulunovsky forestry Alexander Petrovich moved to Ilansky settlement and in the absence of other work he started working as an assistant of Ilansky volost clerk and from here, three months later, he went to work as a registrar at the volost administration in Antsirskoe settlement of Kansk County [AKSRM: ser./f. 7886/213. P. 4]. From about September 1905 until 12 January 1906 he worked as a clerk at Ilanskaya station.

In June 1906 he started to work for M.P. Markov, special assignments officer of Resettlement Administration on migrants' placement and settlement. Alexander Petrovich performed his duties with great scrupulosity and skills, as it can be repeatedly seen from M.P. Markov's letters. But, in spite of his efforts, he was dismissed by the governor's order for participation in the revolutionary events of 1905.

From February 1907 to May 1908, Alexander Petrovich constantly moved from one place to another: he lived in Ilansky, then in Irkutsk, and then again in Kansk and Ilansky.

At the age of 19, he entered into correspondence with the Krasnoyarsk Museum. It concerned, first of all, references about collections. In May 1907 A.P. Ermolaev made an attempt to become a participant of Turukhansk expedition of the Krasnoyarsk Museum, but his letter arrived late: the expedition had already left Krasnoyarsk. And in May 1908, after preliminary correspondence with A.Y. Tugarinov, he moved to Krasnoyarsk and participated as a worker in an expedition organized by A.Y. Tugarinov to the lower reaches of the Yenisei River. Since then, A.P. Ermolaev was a regular volunteer of the museum.

Soon Alexander Petrovich was appointed as an official assistant of A.Y. Tugarinov's museum conservator instead of M.A. Maslennikov [Twenty-Five Years Anniversary ... 1915, p. 33]. According to A.L. Yaworsky's memoirs: "He was a restless explorer and collector. Changing his specialties, he showed not only excellent knowledge of the material in all of them, but also exceptional zeal of a collector. Starting with botany, he became interested in zoology, and especially entomology. Then he mastered ethnography and changed it to archeology. And no matter what he collected, his collections were always numerous and interesting. It was the second Tugarinov in the scope of material and scientific interest in it" [Yaworsky, 2011, p. 219].

Occupying the post of an assistant conservator Alexander Petrovich strived to expand his activities. In 1910 he wrote to the Minusinsk Museum with the request to give him the position of the museum curator. This is evidenced by his letter to I.T. Savenkov: "I would be very grateful if you could inform me if I can expect to occupy the position at the Museum managed by you and if the answer is positive, under what conditions ...”[AMRM, f. 1, ser. 1, 147, p. 1. 54].

Meanwhile, the number of the Krasnoyarsk Museum collections had greatly increased. They were not systematized, and only in 1911, Alexander Petrovich Ermolaev started intensive internal work in the museum. He proceeded with the systematic development and description of the archaeological collections, in particular to the Ceramics Department by gluing the pieces of vessels and put together the pieces on cardboard, and then all the material was photographed, and its detailed description was made. The photo 
album was sent to the Imperial Archaeological Commission, which expressed its appreciation for bringing it "to such a clear and systematic condition". This work took the first half of 1912 [Twenty-Five Years Anniversary ... 1915, p. 50].

In 1910 in the marshes in taiga on a small island near the village of Ishimka, a complex of ancient objects, called the Ishimka treasure was found. On February 16, 1911 a message from the Executive Office of the Yenisei Governor's Selection Committee arrived with a copy of the protocol "of various ancient objects found by a peasant Evtihevii Funtikov" and with a request "to inform whether the objects mentioned in this protocol are of any scientific or historical interest and where the objects should be sent to" [SAKK, f. 217, ser.1, case 52, p.3].

It is natural that such an event as finding treasure could not be neglected by the KDRGS and the Krasnoyarsk Museum.

The regional authorities allocated the matter to the subdivision that responded to the governor with a letter dated 22 February 1911, in which, mentioning the importance of the findings, asked to deliver all the items to the disposition of the Krasnoyarsk Branch of the ESDRGS [SAKK, f. 217, ser. 1, case 52, p. 69].

When in 1911 the museum received a message about the treasure discovery near the village of Ishimka in Achinsk County, A.P. Ermolaev before visiting the place of findings sent a letter to the Achinsk County district police officer in order to obtain the most complete information about the treasure: " 1 . Whether all the items were found in one place, and if they were found separately, what exactly and where? Do the copper objects found separately from the iron ones. 2. How did the objects lay in place where they were found? (in a heap or scattered, or were they fold into something). 3. Where exactly were the objects found: at some distance from the nearest village, river, lake (name them); whether the place has a name (which one exactly), how does the territory look like: a field? a meadow? a steppe? a forest (what kind of)? a river bank? a ravine? a hill? etc. (the more detail description is made the better). How were the objects found: on the ground surface? in the rocks or buried in the ground? (if in the ground, how deep? What was the soil (clay, sand, black earth, firm or loose), are there large stones, debris or whole human and animals' bones? Are there coal and burnt bones and stones from the bonfire site? Were the objects of wood, bone, leather, clay or stone found on the same site? Were there pottery fragments? 4. Was exactly found it: the rank, first name, middle name last name. Under what conditions was the finding made (field works, digging ditches, wells, etc.). 5. How often the old ("Chud") objects made of copper, iron, as well as of bone and stone ("thunderbolts") are found in this area. Do the local people possess any of the findings, and if they do, what exactly and who (first name, second name, address)" [SAKK f.217, ser. 1, case 52, pp. 57-58; Vdovin, 2001, pp. 67-68].

It should be noted that the letter wasn't left unattended, and all the questions were answered. A village constable, who was charged to clarify all the details, presented a report on the information collected. The report contained information about who found the objects, where and in what condition: "1. all the objects were found at one place, the size of which is about a fathom, the copper objects were found separately from the iron ones in the distance of two arshines. 2. The large objects laid one on another and the small objects laid ... apart, randomly. 3. The objects were found on the island about 3 miles from the village of Ishimka. There is a moss marsh with a quaking bog on the one side of it, and a copse with different trees on the other side, then meadows, a lake and Chulym, the distance from Chulym is 4 miles, on the right where the objects were found there is the Ishimka river, the distance to which is 
100 fathoms, the length of the island is about 150 fathoms, the width is 100 fathoms. The objects were found on the depth of 3 inches, the ground is clay loam, loose. 4 . The objects were found by a peasant of Ishimka village, Bolsheuluyskaya volost of Achinsk County of the Yenisei Province Lavrentii Nikit'ev Funtikov during field works. 5. For the first time" [SAKK f. 217, ser. 1, case 52, p. 56].

In the same year, A.P. Ermolaev himself went to the place of the treasure discovery and brought a hoard of bronze and iron objects to the museum. Among the findings there were iron hatchets, swords, daggers, spearheads and arrowheads, bronze mirrors and plaques, as well as images of people, animals and birds, referred to the shamanic accessories. Almost all the objects were found by the villagers, and Ermolaev himself "found a few small fragments of bronze plaques, plates of flattened silver, pieces of burnt wood and coal; 50 steps from them at the other end of the field on the surface plowed ornamented fragments of pots were collected" [Ermolaev A.P., 1914, p. 2].

The entire collection can be divided into three main categories: 1) weapons, 2) ornaments and 3) cult objects. It consisted of about a hundred different types of objects and their fragments: weapons, boiler pieces, mirrors, anthropomorphic and zoomorphic ornaments. A significant part of the Ishim treasure objects found analogy in Aidashinskaya cave and other archaeological sites in Western Siberia. People who left the Ishimka treasure had a rich spiritual world, associated with the cult of bear, wolf, moose, eagles, and other animals and birds. At that, the image of an animal made of reinforced plastic could be formed both in realistic and in schematic styles. Realistic images were even worked out in fine details. But schematic figures of animals with rough edges after casting were of the same importance [Makarov, 2013].

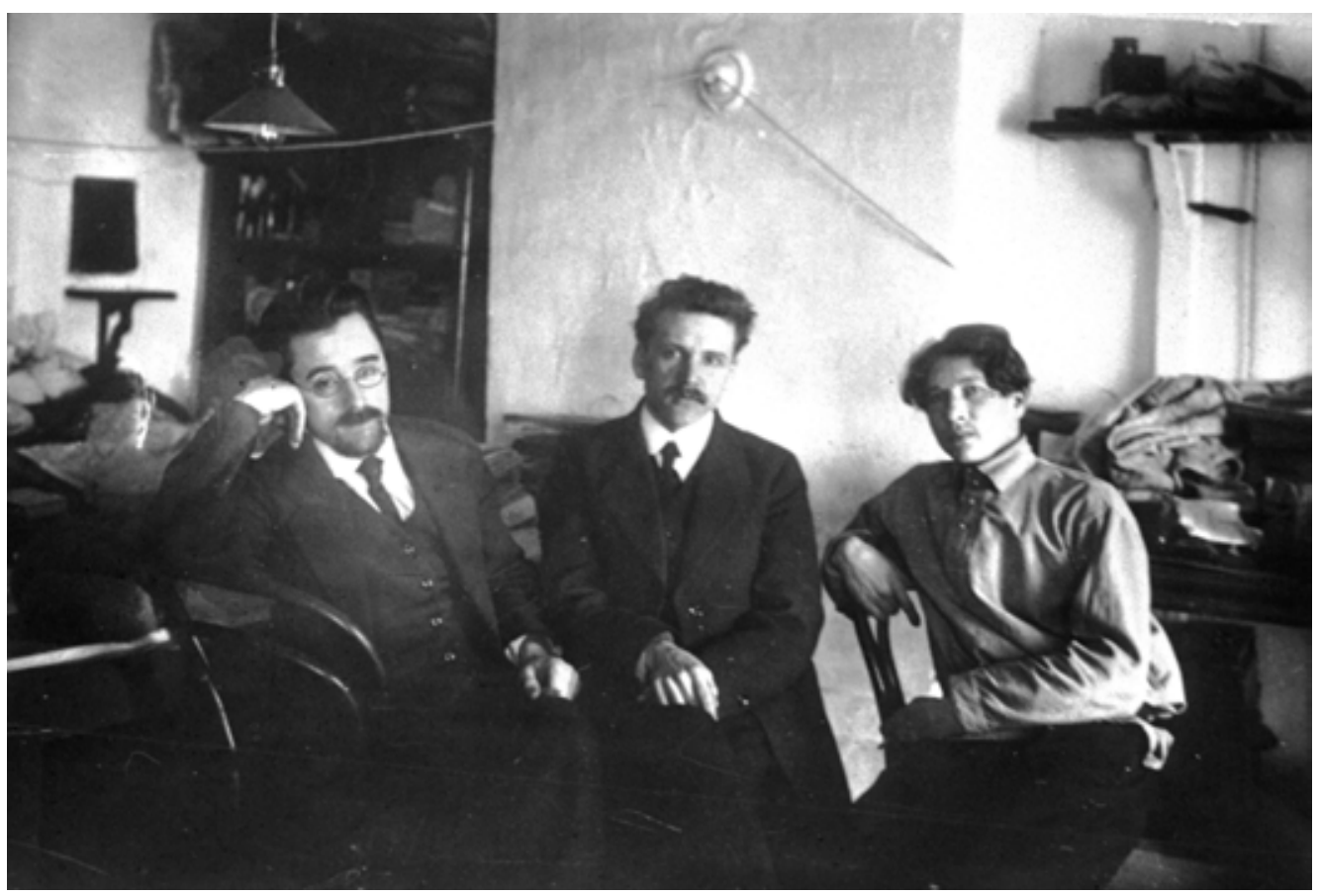

Fig 1. A.P. Ermolaev (in the centre) with his brother V.P. Ermolaev (on the right) and A.Y. Tugarinov (on the left). The Krasnoyarsk Museum. 1913. (KSRM, F. neg. № 5626) 
In the $1^{\text {st }}$ millennium $\mathrm{AD}$ ancestors of a number of modern peoples of Siberia started to form. Coexisting side by side with the tribes of the Tashtyk culture of the developed Iron Age of the Yenisei, the part of the Kulais probably joined polyethnic medieval state "The Kyrgyz Khanate".

Materials of the Ishimka collection were published in a separate edition in 1914. It is noteworthy that at that period the museum did not have descriptions of its collections and data on the number and composition of the latter were only in short annual reports. Meanwhile, the growth of the museum and its departments clearly demonstrated the need to publish descriptions of collections. It was decided to publish "Descriptions of the Krasnoyarsk Museum Collections" - individual issues published in the course of the departments processing. Description of the objects from the Ishimka collection was the first issue of the Department of Archaeology [Ermolaev A.P., 1914, p. 1], along with issued at the same time the book of paleontological collections descriptions (Sobolev, 1914). In a letter to V.A. Gorodtsov, dated 18 January 1914, explaining the choice of the Ishimka collection for printing, A.P. Ermolaev noted the lack of funds. In addition, he shared his plans for the future, noting that the work on the Department of Archaeology collections description would be continued, and the next issue would be focused on the Angara Region archeology and would be much bigger in volume [CHAM, f. 454, ser. 2. case 447. p. 2].

Botany, geology, church archeology and ethnography collections collected by A.P. Ermolaev make up more than a thousand depository items. But the researcher showed the greatest interest studying archaeological monuments. The researcher was in correspondence with P.S. Uvarova, V.A. Gorodtsov, A.A. Spitsin, received small financial support from the Moscow Archaeological Society, actively collaborated with the Archaeological Commission. Having compiled a map of archaeological sites in the area of Lake Shira, A.P. Yermolaev one of the first raised the alarm about the destruction of burial mounds by the railway that was built there (Vdovin, Kuzmin, 2009. p. 30). Sponsored by the scarce funds of the museum A.Y. Tugarinov and A.P. Ermolaev excavated a number of burial mounds in Minusinsk Basin, and were, in fact, the first researchers of Okunev and Andronovo cultures' monuments of the Bronze Age. A.P. Ermolaev also regularly explored sites in the suburbs of Krasnoyarsk and travelled to Uriankhai region. It seemed that the young scientist had a bright future, but his premature death from typhoid fever raging during the Civil War broke everything. His manuscript on the ancient monuments of Lake Shira, Krasnoyarsk suburbs and other areas of Yenisei region in the archives of the Krasnoyarsk Museum were never published [Makarov, Vdovin, 2010].

The outbreak of the First World War and the Revolution didn't give chance to continue publication of the archaeological department's collections of the Krasnoyarsk Museum. Only in 1929, another archaeologist of the Krasnoyarsk Museum, V.A. Gorodtsov's disciple V.G. Kartsov published "Materials in Archeology of the Krasnoyarsk Region. Description of the Museum's Collections and Materials. The Department of Archaeology".

\section{References}

1. Batashev M.S., Vdovin A.S., Makarov N.P. Arkheologo-etnographicheskie issledovaniia A.P. Ermolaeva [Archaeological-Ethnographic Researches of A. P. Ermolaev] // Culture as a System in Historic Context: East-Siberian Archaeological-Ethnographic Meetings Experience. Proceedings 
of the $15^{\text {th }}$ International East-Siberian Archaeological-Ethnographic conference. Tomsk: Agraf-Press, 2010. Pp. 387-390.

2. Vdovin A.S., Guliaeva N.P., Makarov N.P., Batashev M.S., Vasiliev A.D., Vidrin E.V. Russkoe geographicheskkoe obshchestvo v Krasnoyarske [Russian Geographical Society in Krasnoyarsk] (1901-1937). Krasnoyarsk: KSPU Publishing House, 2001. 120 p.

3. Vdovin A.S., Kuz'minikh S.V. Arkheologiia $i$ ministerstvo putei soobshcheniia (na materialakh Sibiri kontsa 19-nachala 20 vv.) [Archaeology and Ministry of Transportation (exemplified by Siberia of the late $19^{\text {th }}$-early $20^{\text {th }}$ Centuries)] // RA, 2009. № 4. Pp. 25-36.

4. Dvadtsatipiteletie Krasnoyarskogo gorodskogo museia [Twenty-Five Years Anniversary of the Krasnoyarsk City Museum]. Krasnoyarsk, 1915. 168 p.

5. Ermolaev A.P. Ishimskaia kollektsiia. Opisanie kollektsii Krasnoyarskogo Museia [The Ishimka Collection. Description of the Krasnoyarsk Museum Collections]. Iss. I. Krasnoyarsk, 1914. $28 \mathrm{p}$.

6. Kartsov V.G. Materiali $k$ arkheologii Krasnoyarskogo raiona. Opisanie kollektsii $i$ materialov museia. Otdel arkheologicheskii [Materials in Archeology of the Krasnoyarsk Region. Description of the Museum's Collections and Materials. The Department of Archaeology]. Krasnoyarsk, 1929. $53 \mathrm{p}$.

7. Makarov N.P. Arkheologicheskie kladi iz fondov Krasnoyarskogo muzeia kak istochnik po mirovozzreniiu drevnikh i traditsionnikh obshchestv [Archaeological Treasures from the Krasnoyarsk Museum Funds as a Source of Ancient and Traditional Societies' Worldviews] // Integration of Archaeological and Ethnographic Researches. Irkutsk: IrSTU Publishing House, 2013. Vol. 2. Pp.79-82.

8. Makarov N.P., Vdovin A.S. Arkheologiia v Krasnoyarskom Musee [Archaeology in the Krasnoyarsk Museum] // Man and Ancientries. In Memoriam of Alexander Alexandrovich Formozov (1928-2009). M.: Grif i K, 2010. Pp. 678-683.

9. Yaworsky A.L. Dvadtsat' let na Enisee [Twenty Years on the Yenisei River] // Dedicated to Arkadii Yakovlevich Tugarinov ... Krasnoyarsk, 2011. Pp.151-359. 


\title{
А.П. Ермолаев и первое описание археологической коллекции Красноярского музея
}

\author{
А.А. Малицкая, \\ Н.П. Макаров, А.С. Вдовин \\ Красноярский государственный педагогический университет \\ им. В. П. Астафьева \\ Россия, 660049, Красноярск, ул. Ады Лебедевой, 89
}

В данной статье представлена биография помощника консерватора Красноярского городского музея А.П. Ермолаева. Дан краткий обзор его научной деятельности как археолога. На основе малоизвестных архивных данных публикуются сведения об особенностях обнаружения, сбора информации и публикаџии уникального Ишимского клада развитого железного века-эпохи раннего Средневековья.

Ключевые слова: музееведение, Красноярский краеведческий музей, А.П. Ермолаев, археология, железный век, Средневековье, Ииимский клад.

Научная специальность: 07.00.00 - исторические науки. 